\title{
Complement metabolism in rheumatoid arthritis
}

\section{Longitudinal studies}

\author{
J. M. B. VERSEY, J. R. HOBBS, AND P. J. L. HOLT* \\ From the Department of Chemical Pathology, Westminster Medical School, London, and the \\ Rheumatology Unit, Royal Postgraduate Medical School, London
}

Reduced serum complement levels are well documented in systemic lupus erythematosus (SLE) (Schur and Austen, 1968), and complement-mediated inflammation is thought to be a pathogenetic mechanism in this disease (Miescher and Paronetto, 1969). Variation in the complement level probably reflects the disease activity (Townes, 1967; Schur and Sandson, 1968) and response to treatment (Ruddy, Everson, Schur, and Austen, 1971a).

Rheumatoid arthritis is a clinically similar disease in which immunological mechanisms are also implicated. However, the significance of complement involvement in this disease has not been as extensively studied. Studies of static serum levels of complement components are not in themselves indicative of complement participation. More direct evidence of complement involvement in rheumatoid arthritis is the presence of IgG- $\mathrm{B}_{1} \mathrm{C}$ complexes in synovial fluid (Vaughan, Barnett, Sobel, and Jacox, 1968) and synovial cells (Hurd, LoSpalluto, and Ziff, $1969,1970)$. Increased complement consumption has been demonstrated by turnover studies of C3 component using radiolabelled C3 (Weinstein, Peters, Brown, and Bluestone, 1972) and is associated with raised immunoconglutinin levels (Marks and Coombs, 1957; Mustakallio and Kalliomäki, 1968).

Activation of the complement system and utilization of complement is associated with the production from the parent complement components of smaller fragments. These fragments-'inactivation products' - retain some of the antigenic characteristics of the parent molecule and cross-react with antisera prepared against the parent molecule, but have a different electrophoretic mobility.

The present investigations were undertaken to see if the individual fragments produced during complement consumption could be demonstrated in rheumatoid arthritis serum and if so to assess their significance and value in following treatment. To enable this to be done, a semi-automated modification of the two-dimensional technique of Clarke and Freeman (1968) was developed. The technique used depends on the identification and measurement of $\mathrm{C} 3$ and $\mathrm{C} 4$ and their inactivated (converted) components $\mathrm{C} 3 \mathrm{i}$ and $\mathrm{C} 4 \mathrm{i}$ by immunochemical means, using an oligospecific antiserum. The method has been proven to be sensitive and reproducible.

\section{Materials and methods}

All patients were outpatients. Those with rheumatoid arthritis all had classical disease by ARA criteria (Ropes, Bennett, Cobb, Jacox, and Jessar, 1959). Clinical activity was measured by grip strength and activity index (Ritchie, Boyle, McInnes, Jasani, Dalakos, Grieveson, and Buchanan, 1968). Blood samples were taken both at morning and afternoon clinics. The erythrocyte sedimentation rate (ESR) was measured by the Westergren method, using $2 \mathrm{ml}$. freshly drawn blood and $0.5 \mathrm{ml} .3 .8$ per cent. sodium citrate, and reading at one hour. Waaler-Rose titres were estimated as a differential agglutination ratio, all sera from a single patient being tested together. Plasma was obtained before gold injections by drawing blood into EDTA tubes, the plasma being stored at $-20^{\circ} \mathrm{C}$. until used and thawed once at the time of estimation of complement. No sample for complement estimation was used after 3 weeks. Storage at $-70^{\circ} \mathrm{C}$. is recommended for longer periods.

\section{TREATMENT}

Four patients, none of whom showed response to gold therapy, were followed through the course of their trial of treatment with gold, two of these patients were being treated with prednisone $(7.5 \mathrm{mg}$. and $12.5 \mathrm{mg}$. respectively throughout, the dose of which was kept constant. The patients received sodium aurothiomalate in doses from 20 to $80 \mathrm{mg}$. intramuscularly at weekly or fortnightly intervals. Analgesics were used as necessary (paracetamol or dextropropoxyphene). In all cases measurements of complement commenced with the start of chrysotherapy. 
None of the rheumatoid patients or controls had received corticosteroids or gold injections in the preceding 6 months. All the disease controls had active disease but were not on corticosteroid therapy at the time of taking blood samples.

MEASUREMENT OF COMPLEMENT CONVERSION Using a semi-automated two-dimensional immunoelectrophoretic method previously described (Versey, 1971), conversion of $C 3$ and C4 was estimated. A single sheep antiserum against human plasma $\beta$-region, with proven reactivity for $\mathrm{C} 3, \mathrm{C} 4$, and transferrin, was used throughout. Area measurements of the resultant peaks are calculated by planimetry, but simple area measurement by the triangular technique results in only slight loss of accuracy (Versey and Slater, 1973). Transferrin, used as the internal standard, was measured accurately in each plasma sample by rocket electrophoresis (Laurell, 1966), using a monospecific rabbit antiserum against purified transferrin (Behringerwerke). C3 and C4 concentrations can then be expressed in transferrin units by the following formula:

$$
\begin{gathered}
\frac{\text { area of unknown peak }}{\text { area of transferrin peak }} \times \text { concentration of transferrin } \\
=\text { concentration of unknown peak }
\end{gathered}
$$

Calibration of $\mathrm{C} 3$ in $\mathrm{mg} . / 100 \mathrm{ml}$. was achieved by comparison with reference serum (Hoechst), a purified C3 preparation (Hyland Laboratories) and our own calculated normal range, giving mg. equivalent of approximately two transferrin units for the antiserum. Conversion factors for $\mathrm{C} 3$ and $\mathrm{C} 4$ were determined by total conversion of known quantities of $\mathrm{C} 3$ and $\mathrm{C} 4$ at $37^{\circ} \mathrm{C}$. to $\mathrm{C} 3 \mathrm{i}$ and $\mathrm{C} 4 \mathrm{i}$.

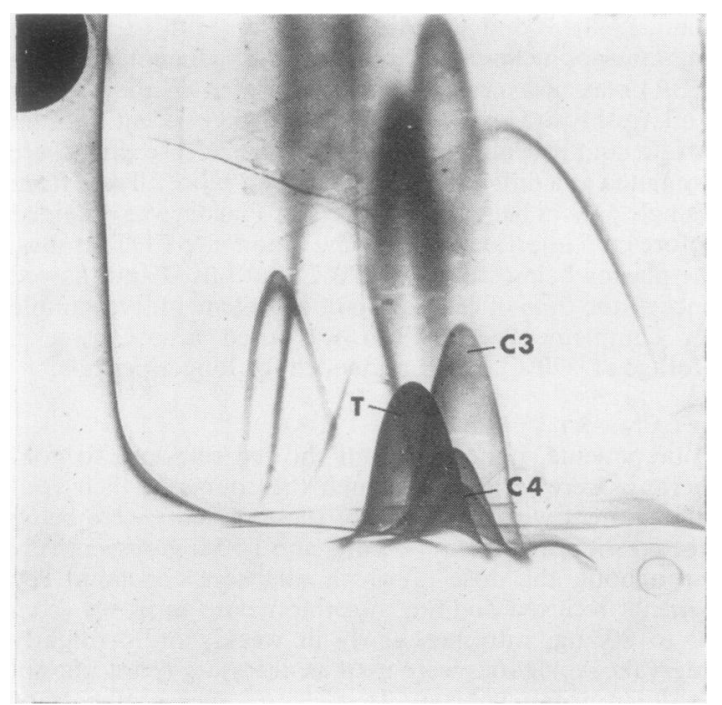

FIG. 1 Two-dimensional immuno-electrophoresis of normal serum, showing uniform outline of both $C 3$ and $C 4$ complement peaks, with no evidence of conversion products. $\boldsymbol{T}=$ transferrin
With this anti-human $\beta$-region serum, no such conversion factor appears necessary, and thus conversion can be expressed directly in $\mathrm{mg}$. $/ 100 \mathrm{ml}$. or in percentage conversion of total $\mathrm{C} 3$ or $\mathrm{C} 4$. Total $\mathrm{C} 3$ and $\mathrm{C4}$ were measured from the two-dimensional plates as the areas of each component plus its converted material.

\section{Results}

NORMAL SERA

Normal sera contained uniform peaks of $\mathrm{C} 3$ and $\mathrm{C} 4$ without continuation as the inactivation products $\mathrm{C} 3 \mathrm{i}$ and $\mathrm{C} 4 \mathrm{i}$ (Fig. 1). The transferrin peak used as a standard is clearly seen. The range of $\mathrm{C} 3$ and $\mathrm{C} 4$ levels is wide in normal individuals (Table I). Conversion products were rarely found in normal sera and then only to a small extent. In the longitudinal studies little variation in complement levels occurred and conversion products were rarely found in normal individuals.

Table I Serum complement (C3 and C4) and con-

\begin{tabular}{|c|c|c|c|c|}
\hline $\begin{array}{l}\text { Subject } \\
\text { no. }\end{array}$ & $\begin{array}{l}\text { C3 (mg. } \\
\text { per cent.) }\end{array}$ & $\begin{array}{l}\text { C3i (mg. } \\
\text { per cent.) }\end{array}$ & $\begin{array}{l}\text { C4 } \\
\text { (units) }\end{array}$ & $\begin{array}{l}\text { C.4i } \\
\text { (units) }\end{array}$ \\
\hline $\begin{array}{l}1 \\
2\end{array}$ & $\begin{array}{l}160 \\
150\end{array}$ & - & $\begin{array}{l}85 \cdot 1 \\
38 \cdot 2\end{array}$ & 二 \\
\hline 3 & 147 & - & 106.0 & - \\
\hline 4 & 142 & - & $23 \cdot 1$ & - \\
\hline 5 & 137 & - & 93.8 & - \\
\hline 6 & 137 & - & 48.9 & - \\
\hline 7 & 136 & - & $42 \cdot 1$ & - \\
\hline 8 & 124 & - & $19 \cdot 2$ & - \\
\hline 9 & $113 \cdot 7$ & - & 108.5 & - \\
\hline 10 & 112 & - & 52.0 & - \\
\hline 11 & 97 & - & $72 \cdot 2$ & - \\
\hline 12 & 94 & - & $44 \cdot 1$ & - \\
\hline 13 & 94 & - & 58 & - \\
\hline 14 & 93 & - & $63 \cdot 0$ & - \\
\hline 15 & $90 \cdot 5$ & - & $26 \cdot 4$ & - \\
\hline 16 & $89 \cdot 5$ & - & $19 \cdot 2$ & - \\
\hline 17 & 86.0 & - & $9 \cdot 4$ & 1.0 \\
\hline 18 & 80 & $1 \cdot 1$ & $46 \cdot 1$ & - \\
\hline 19 & 76 & - & 31 & - \\
\hline 20 & 73 & - & 61 & - \\
\hline Mean & $\begin{array}{c}113.9 \\
35 .\end{array}$ & & $\begin{array}{c}52 \cdot 35 \pm \\
\cdot 18\end{array}$ & \\
\hline
\end{tabular}
version products $(C 3 i$ and $C 4 i)$ in 20 normal subjects

However, in both Table I and Figs 2 and 3, sera which showed conversion have been purposely included to emphasize that this may occur to a small degree even in normal people. No significant variation of complement levels with age or sex was found.

RHEUMATOID SERA

There was a tendency for the levels of both C3 and $\mathrm{C} 4$ to be elevated but with a very wide range of values (Table II, opposite). However, it was in the presence of conversion products (Fig. 4, opposite) that the greatest divergence was seen, eleven of twenty patients ( 55 per cent.) having $\mathrm{C} 4$ conversion and fifteen patients (75 per cent.) C3 conversion. Moreover, 


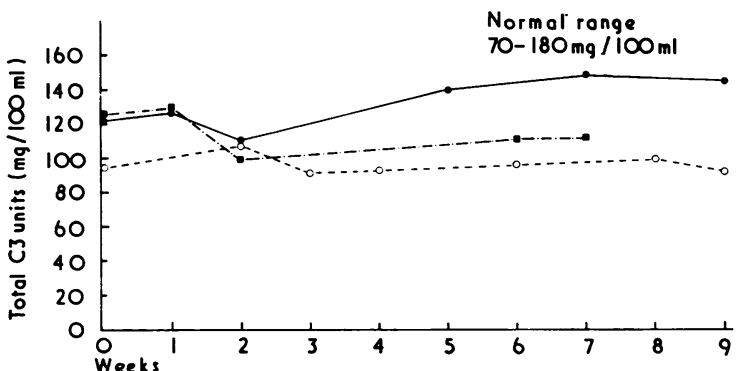

Table II Serum C3, C4, C3i, and C4i levels in random sera from 20 patients with rheumatoid disease

\begin{tabular}{|c|c|c|c|c|c|}
\hline $\begin{array}{l}\text { Patient } \\
\text { no. }\end{array}$ & $\begin{array}{l}\text { C3 } \\
\text { (mg. } \\
\text { per cent.) }\end{array}$ & $\begin{array}{l}\text { C3i } \\
\text { (mg. } \\
\text { percent.) }\end{array}$ & $\begin{array}{l}\text { C4 } \\
\text { (units) }\end{array}$ & $\begin{array}{l}C 4 i \\
\text { (units) }\end{array}$ & $\begin{array}{l}E S R \\
(\mathrm{~mm} . \\
\text { lst } \mathrm{hr})\end{array}$ \\
\hline $\begin{array}{l}1 \\
2 \\
3 \\
4 \\
5 \\
6 \\
7 \\
8 \\
9 \\
10 \\
11 \\
12 \\
13 \\
14 \\
15 \\
16 \\
17 \\
18 \\
19 \\
20\end{array}$ & $\begin{array}{r}198 \\
191 \\
185 \\
179 \\
167 \\
155 \\
150 \\
148 \\
140 \\
137 \\
113 \\
105 \\
101 \\
99 \\
95 \\
89 \\
84 \\
80 \\
80 \\
70\end{array}$ & $\begin{array}{c}10 \cdot 2 \\
2 \cdot 1 \\
5 \cdot 1 \\
2 \cdot 0 \\
\overline{3} \cdot 8 \\
- \\
8 \cdot 2 \\
2 \cdot 0 \\
8 \\
3 \cdot 8 \\
2 \cdot 2 \\
3 \cdot 2 \\
5 \cdot 7 \\
4 \cdot 8 \\
\overline{-} \\
3 \cdot 3 \\
\overline{4} \cdot 9\end{array}$ & $\begin{array}{c}144 \\
139 \\
82 \\
42 \\
118 \\
63 \\
147 \\
59 \cdot 4 \\
52 \\
40 \\
35 \\
61 \\
56 \cdot 7 \\
23 \\
38 \\
57 \\
9 \cdot 8 \\
52 \cdot 5 \\
18 \cdot 3 \\
31 \cdot 8\end{array}$ & $\begin{array}{l}20 \cdot 2 \\
\overline{2} \\
2 \cdot 9 \\
\frac{18 \cdot 8}{\overline{8}} \\
8 \cdot 6 \\
1 \cdot 2 \\
11 \cdot 5 \\
0.7 \\
\overline{0} \\
\overline{0} \cdot 4 \\
\overline{0} \cdot 7 \\
6.7 \\
\overline{1} \cdot 5\end{array}$ & $\begin{array}{l}32 \\
30 \\
14 \\
40 \\
32 \\
\frac{49}{79} \\
\frac{70}{85} \\
\frac{98}{-} \\
\frac{2}{20} \\
50 \\
28 \\
-\end{array}$ \\
\hline Mean & $128 \cdot 2$ & - & $62 \cdot 9$ & - & - \\
\hline
\end{tabular}

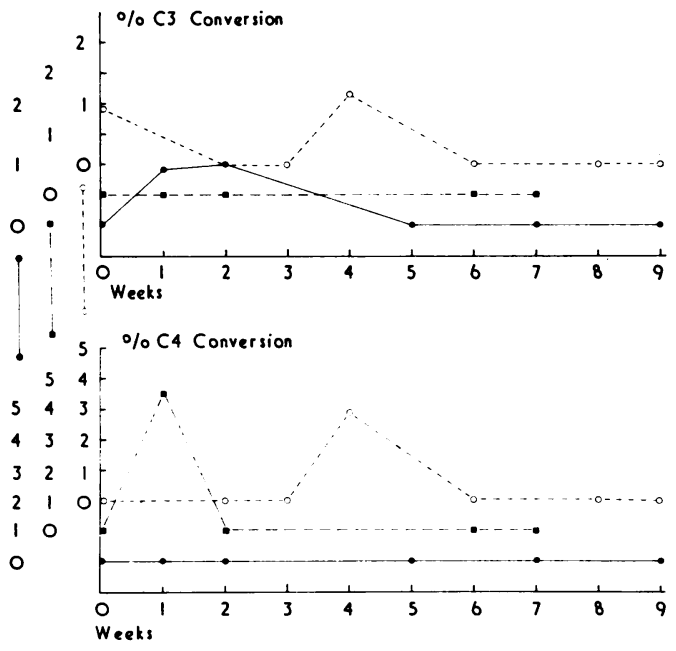

FIG. 3 Serial serum conversion product levels (C3i and $C 4 i)$ in the same controls as Fig. 2. Note varying baseline

these were raised to a greater degree than was found in the normal sera. In the patients' sera the continual variation in all parameters measured was marked and usually unassociated with obvious clinical change (Figs 5, 6, 7, overleaf). One of the patients (Fig. 5) had recurrent episodes of digital vasculitis and nodule formation, which was not reflected by changes in complement metabolism. A good correlation between the fluctuations of the two complement conversion component levels was noted (Figs $5,6,7$ ), but no relationship with complement levels (C3 or C4). In

FIG. 4 Serum from a rheumatoid patient. Conversion products $C 3$ i and $C 4$ i of both $C 3$ and $C 4$ form faster secondary peaks

these patients gold did not seem to have any effect on complement, erythrocyte sedimentation rate, and Waaler-Rose titres, nor did it affect the clinical status.

SYSTEMIC LUPUS ERYTHEMATOSUS SERA

The pattern of conversion is again slightly different (Fig. 8); the levels of $\mathrm{C} 3$ are decreased, but $\mathrm{C} 4$ levels 


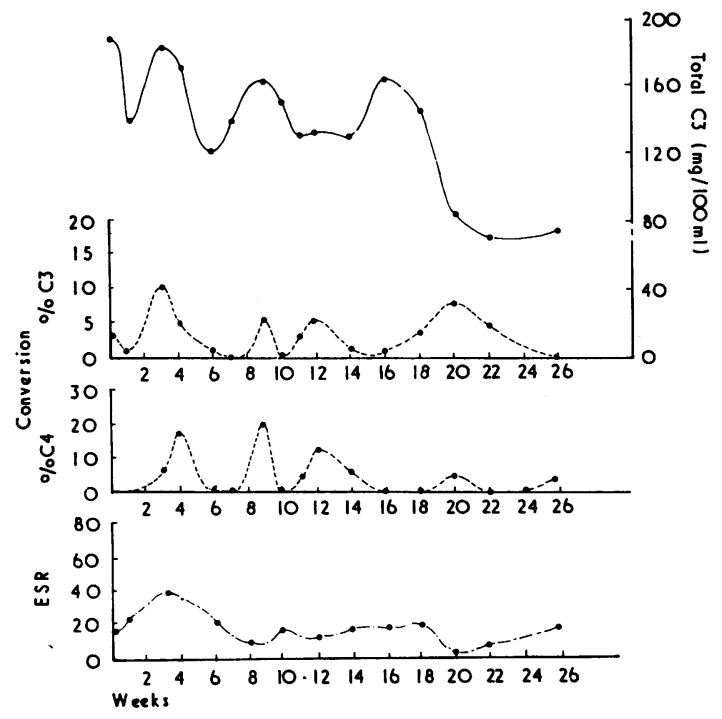

FIG. 5 Serial serum complement and conversion product levels in a rheumatoid patient

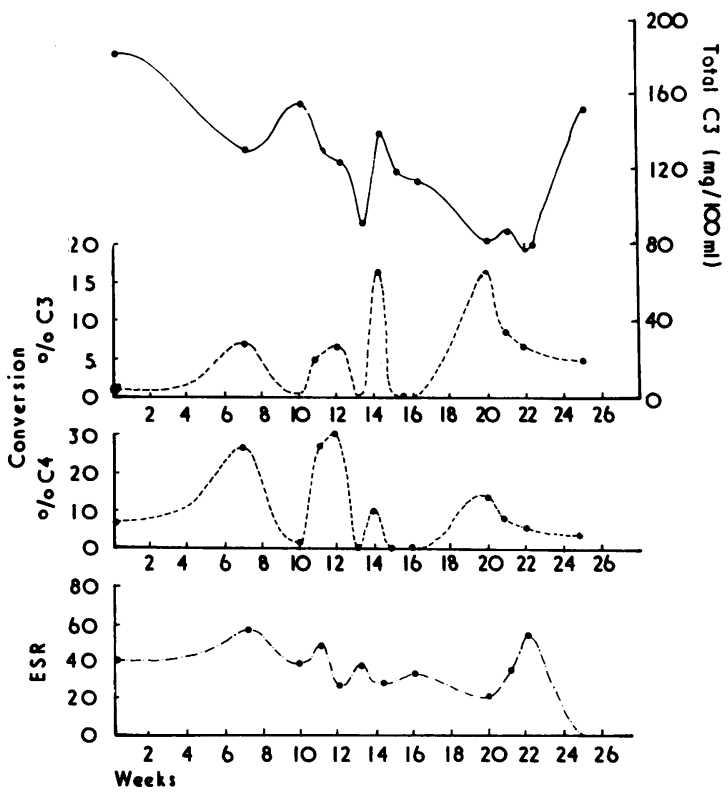

FIG. 6 Rheumatoid patient, similar to Fig. 5

tend to be within the normal range (Table III). Conversion products of both $\mathrm{C} 3$ and $\mathrm{C} 4$ were frequently found. It was felt to be unrealistic to undertake serial estimations since these patients were being treated and their clinical status fluctuated.

\section{DISEASE CONTROLS}

Sera from patients with a variety of inflammatory and neoplastic diseases were tested and again a tendency for elevated C3 levels but normal C4 levels was found

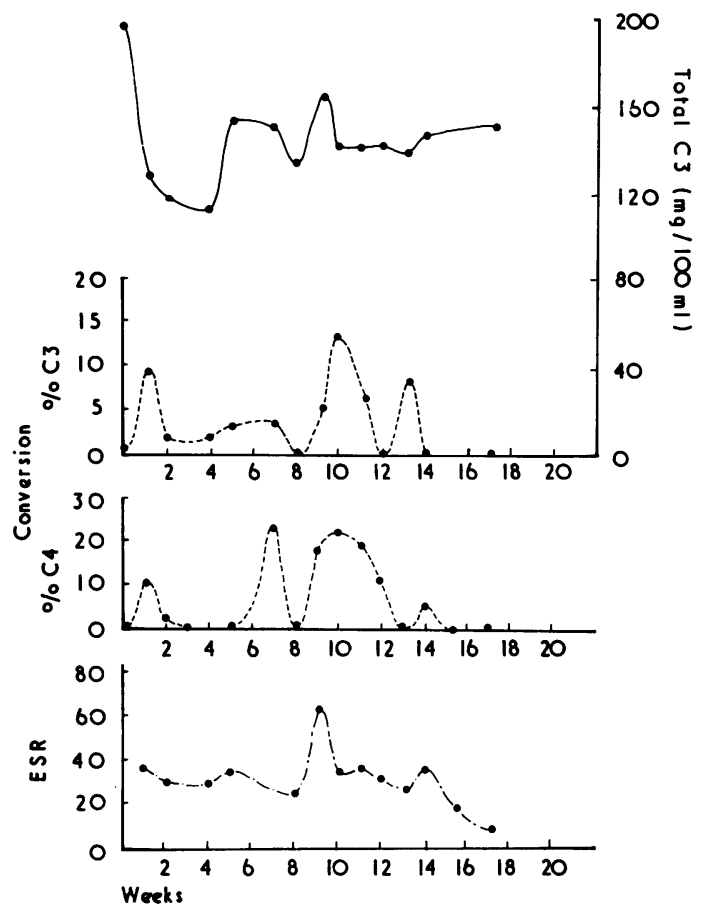

FIG. 7 Rheumatoid patient, similar to Figs 5 and 6

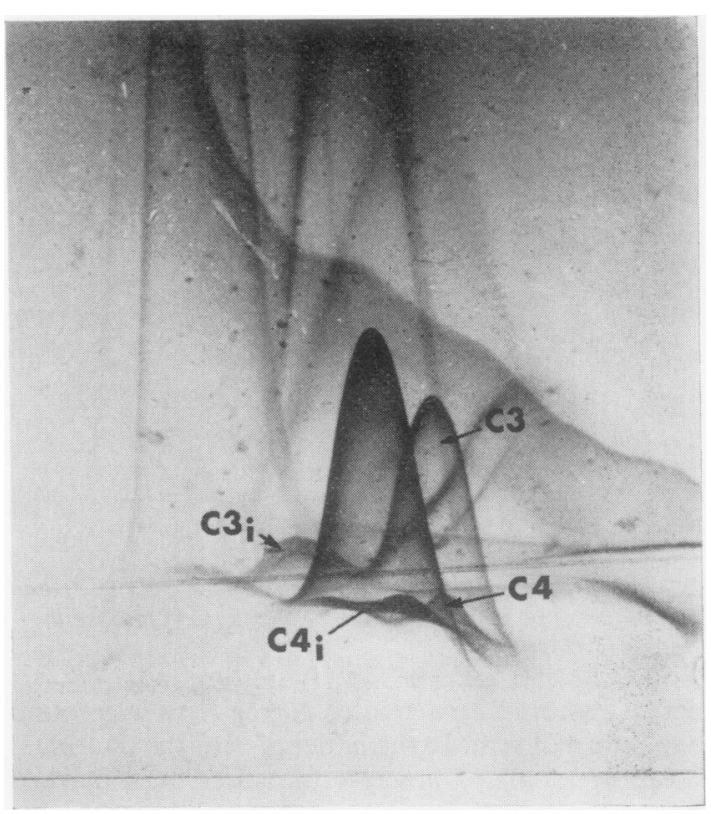

FIG. 8 Serum from a patient with active systemic lupus erythematosus. Both $C 3$ and $C 4$ peaks are markedly reduced and have associated conversion products

(Table IV). Conversion products were common. Correlation with clinical activity is impossible because of the diversity of diseases and treatments employed. 
Table III Serum C3,C4,C3i, and C4i levels in random sera from 8 patients with systemic lupus erythematosus

\begin{tabular}{|c|c|c|c|}
\hline$C 3$ & $C 3 i$ & $C 4$ & $C 4 i$ \\
\hline $\begin{array}{r}169 \\
102 \\
100 \\
78 \\
72 \\
55 \\
53 \\
13\end{array}$ & $\begin{array}{l}2 \cdot 7 \\
23 \\
2 \cdot 1 \\
1.6 \\
4.0 \\
3.9 \\
0.2\end{array}$ & $\begin{array}{l}92 \\
54 \\
40 \\
44 \cdot 8 \\
58 \cdot 4 \\
48 \\
24 \\
63\end{array}$ & 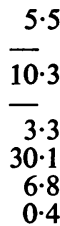 \\
\hline
\end{tabular}

Table IV Serum complement levels in 21 patients with inflammatory diseases

\begin{tabular}{|c|c|c|c|c|}
\hline Diagnosis & $\begin{array}{l}\text { C3 } \\
\text { (mg. } \\
\text { per } \\
\text { cent. })\end{array}$ & $\begin{array}{l}\text { C3i } \\
(\mathrm{mg} . \\
\text { per } \\
\text { cent. })\end{array}$ & $\begin{array}{l}\text { C4 } \\
\text { (units) }\end{array}$ & $\begin{array}{l}\text { C4i } \\
\text { (units) }\end{array}$ \\
\hline $\begin{array}{l}\text { Pneumonia } \\
\text { Pneumonia }\end{array}$ & $\begin{array}{l}89 \cdot 2 \\
120\end{array}$ & $\begin{array}{r}6 \cdot 3 \\
12 \cdot 6\end{array}$ & $\begin{array}{l}29 \cdot 4 \\
80 \cdot 6\end{array}$ & $\begin{array}{l}13 \cdot 4 \\
25 \cdot 3\end{array}$ \\
\hline $\begin{array}{l}\text { Hodgkin's disease } \\
\text { Hodgkin's disease } \\
\text { Hodgkin's disease }\end{array}$ & $\begin{array}{l}181 \\
203 \\
69 \cdot 7\end{array}$ & $\begin{array}{l}5 \cdot 3 \\
2 \cdot 9 \\
-\end{array}$ & $\begin{array}{l}20 \cdot 1 \\
10 \cdot 5 \\
52 \cdot 8\end{array}$ & $\begin{array}{l}26 \cdot 1 \\
5 \cdot 6 \\
-\end{array}$ \\
\hline Melanoma & 127 & - & $47 \cdot 5$ & - \\
\hline $\begin{array}{l}\text { Polymyalgia rheumatica } \\
\text { Polymyalgia rheumatica } \\
\text { Polymyalgia rheumatica }\end{array}$ & $\begin{array}{l}141 \\
127 \cdot 5 \\
123\end{array}$ & $\begin{array}{l}1 \cdot 6 \\
0.9 \\
0 \cdot 7\end{array}$ & $\begin{array}{l}35 \\
45 \\
46 \cdot 9\end{array}$ & $\begin{array}{l}1 \cdot 2 \\
5 \cdot 0 \\
-\end{array}$ \\
\hline Chronic active hepatitis & 80 & 1.5 & $10 \cdot 3$ & $3 \cdot 0$ \\
\hline $\begin{array}{l}\text { Hereditary angioneurotic } \\
\text { oedema }\end{array}$ & 184 & - & 23 & - \\
\hline $\begin{array}{l}\text { Polyarteritis nodosa } \\
\text { Polyarteritis nodosa } \\
\text { Polyarteritis nodosa }\end{array}$ & $\begin{array}{r}125 \\
115 \\
68\end{array}$ & $\bar{z}$ & $\begin{array}{l}70 \cdot 3 \\
62 \\
38 \cdot 4\end{array}$ & 二 \\
\hline $\begin{array}{l}\text { Glomerulonephritis } \\
\text { Glomerulonephritis } \\
\text { Glomerulonephritis } \\
\text { Glomerulonephritis }\end{array}$ & $\begin{array}{r}190 \\
142 \\
92 \\
88\end{array}$ & $\overline{\overline{-}}$ & $\begin{array}{l}60 \\
60 \\
63 \\
38\end{array}$ & $\begin{array}{l}\bar{z} \\
\overline{0} \cdot 2\end{array}$ \\
\hline $\begin{array}{l}\text { Syphilis } \\
\text { Syphilis }\end{array}$ & $\begin{array}{l}232 \\
155\end{array}$ & 二 & $\begin{array}{l}38 \\
44\end{array}$ & $\begin{array}{l}4 \cdot 0 \\
8 \cdot 0\end{array}$ \\
\hline Sarcoid & 105 & 69 & 89 & $3 \cdot 0$ \\
\hline
\end{tabular}

\section{Discussion}

These results demonstrate that accurate measurement of $\mathrm{C} 3$ and $\mathrm{C} 4$ levels and their conversion products are possible and that in healthy individuals there is little day-to-day variation of $\mathrm{C} 3$ and $\mathrm{C} 4$ levels, and that virtually no conversion products are normally present in serum. The absence of detectable conversion products may simply mean that these are produced in quantities too small to be measured at the sensitivity employed. Thus the detection of any conversion product by this method is probably significant (provided that EDTA plasma is used as described.)

The conversion demonstrated probably reflects the situation in vivo and is not an artefact in vitro for the following reasons. No significant conversion can be detected in normal plasma and no significant increase occurs in that already present in rheumatoid plasma over 4 hours. Slow conversion can be demonstrated in plasma allowed to stand at room temperatures, when, however, conversion of $\mathrm{C} 3$ occurs to the same extent for both normal and rheumatoid plasma and without much $\mathrm{C} 4$ conversion, thereby clearly differing from the present findings.

With such wide ranges for the normal complement levels, it is difficult to evaluate the significance of a single C3 or C4 level in rheumatoid arthritis and SLE, where, as we have shown, there may be an overlapping range of $\mathrm{C} 3$ or $\mathrm{C} 4$ levels with the normal. However, changing values for complement component levels in a single patient may be useful in following the progress of the disease. Alper and Rosen (1967), Petz, Fink, Letsky, Fudenberg, and Müller-Eberhard (1968), and Weinstein and others (1972) recognized that hypercatabolism of C3 could occur in SLE, haemolytic anaemia, and rheumatoid arthritis with normal levels of serum $\mathrm{C} 3$ and $\mathrm{CH}_{50}$, and thus that a complement level may not indicate the degree of complement utilization. Our results show that this is in fact usually the case. Although turnover studies have shown decreased complement synthesis in SLE (Sliwinski and Zvaifler, 1972) and increased synthesis in rheumatoid arthritis (Weinstein and others, 1972), decreased catabolism may occur in some patients with rheumatoid arthritis (Alper and Rosen, 1967).

Elevation of complement level seems to occur in many inflammatory conditions when the disease is active (Vaughan, Bayles, and Favour, 1951 ; Ellis and Felix-Davies, 1959; Jonsen and Kåss, 1961), presumably because of increased synthesis. This explains the shape of our curves whereby the elevation of complement (C3 or C4) is often associated with increased rates of complement conversion ( $\mathrm{C} 3 \mathrm{i}$ and $\mathrm{C} 4 \mathrm{i})$, conversion of both $\mathrm{C} 3$ or $\mathrm{C} 4$ occurring in unison. Conversely, low $\mathrm{CH}_{50}$ levels have been found to be associated with the complications of rheumatoid arthritis (Franco and Schur, 1971). The opposite effect is found in SLE, where activity and complement conversion is associated with reduced complement levels (Sliwinski and Zvaifler, 1972).

The spontaneous fluctuation of complement levels during the course of the disease is interesting and has been noted previously (Schubart, Ewald, Schroeder, Rothschild, Bhatavadekar, and Pullen, 1965). Thus rheumatoid disease, by these immunological parameters, is seen as a variable and even episodic 
disorder. The current approach may offer a sensitive monitor for disease activity. Ruddy and others (1971a) have shown a good correlation between $\mathrm{C} 9$ and the erythrocyte sedimentation rate, less marked correlation of $\mathrm{CH}_{50}$ and $\mathrm{Cl}$ with the erythrocyte sedimentation rate, but no correlation between $\mathrm{C} 4$ or $\mathrm{C} 2$ levels and the erythrocyte sedimentation rate. From the present results, however, it will be obvious that isolated values for complement should not be used in judging the relative severity of the disease in individual patients with rheumatoid arthritis.

The source of the conversion products is not clear. Complement consumption probably indicates active humoural immunity and immune complex formation, and this is made more likely since the $\mathrm{C} 4 \mathrm{i}$ and $\mathrm{C} 3 \mathrm{i}$ levels fluctuate in parallel, which would not happen if entry by the alternate pathway (Götze and MüllerEberhard, 1971) or non-specific proteolysis was the main route of complement degradation. They may arise either from the inflamed joints or from intravascular sites. In synovial fluid, the presence of lowered complement levels (Ruddy and Austen, 1970; Townes and Sowa, 1970), together with the greater rate of catabolism of intra-articular compared with intravascularly administered C3 (Ruddy, MüllerEberhard, and Austen, 1971b), suggests that one source of complement degradation products is from the joint. Diffusion of C3i (mol. weight $\sim 120,000$ ) across the synovial membrane probably occurs fairly rapidly, since radioactive complement given into the joint is rapidly found in the systemic circulation and larger molecules, e.g. IgM, also move readily across the inflamed synovial membrane. The association of increased C3 catabolism with vasculitis (Weinstein and others, 1972) may reflect either the severity of the disease processes or complement consumption within the circulation, although the latter has not been demonstrated (Douglas, 1965). In the one patient (Fig. 5), who developed recurrent vasculitic lesions and nodules during the course of his treatment, no association with the complement pattern was seen.

The interrelations between rheumatoid factors and complement are numerous. Rheumatoid factor levels may simply reflect disease activity or may influence the metabolism of complement. $\mathrm{CH}_{50}$ levels tend to be lower in seropositive than in seronegative patients (Mongan, Cass, Jacox, and Vaughan, 1969); moreover, subnormal levels are more often associated with severe disease, particularly vasculitis (Franco and Schur, 1971). Systemic catabolic rates are elevated in seropositive but not in seronegative patients, even in the absence of vasculitis (Ruddy and others, 1971b). Lowered complement levels in rheumatoid synovial fluid seem to be related to the level of rheumatoid factor present (Hedberg, 1967; Winchester, Agnello, and Kunkel, 1970). Precipitation of synovial fluid complexes of IgG by IgM rheumatoid factor occurs (Hannestad, 1967). More recently IgG has been demonstrated in the sera of many patients with rheumatoid arthritis which is precipitable with IgM rheumatoid factors but not precipitable with Clq, in contradistinction to the complexes found in rheumatoid synovial fluid (Winchester and others, 1970). Zvaifler (1969) has shown that addition of aggregated IgG to serum containing rheumatoid factor causes conversion of $\mathrm{C} 3$.

This work confirms that complement metabolism is commonly altered in rheumatoid disease, and that the degree of alteration is constantly changing.

\section{Summary}

A method of demonstrating serum complement (C3 and $\mathrm{C} 4$ ) breakdown by measuring the inactivation products present is described. Complement conversion is seldom found in normal sera but is frequent in sera from patients with rheumatoid arthritis, systemic lupus erythematosus, and a variety of inflammatory conditions. The degree of conversion is continually varying, but although the levels of conversion products do not bear any relationship to level of the parent molecule, in rheumatoid arthritis $\mathrm{C} 3 \mathrm{i}$ and $\mathrm{C} 4 \mathrm{i}$ levels tend to fluctuate together.

We should like to acknowledge the technical assistance of Mrs. R. Evans and Miss L. Slater, and financial help from the Medical Research Council and the Arthritis and Rheumatism Council for Research. We also thank Mrs. J. Andrews for her help.

\section{Discussion}

DR. ORLOFF (Brussels) Rheumatoid arthritis is a chronic disease; would the same sort of reasoning hold for a chronic disease like tuberculosis or leprosy, in both of which diseases the rheumatoid factor may be demonstrated?

DR. HOLT We have looked at tuberculosis and in the inactive stages complement inactivation was not present.

DR. MAINI (London) Firstly, have you looked at complement inactivation products in synovial fluids in rheumatoid arthritis, and secondly have you examined sera from rheumatoid patients complicated by vasculitis?

DR. HOLT Other people have looked, using a similar, rather cruder technique, and have shown inactivation products in synovial fluid, and we have confirmed this. The serum levels are not particularly high in vasculitis and, in fact, one of the patients that I showed had recurrent episodes of vasculitis with no correlation with the serum level of complement inactivation products.

DR. A. G. MOW AT (Oxford) I know that Dr Weinstein working in your department has already published results of complement turn-over times in rheumatoid patients, particularly those with vasculitis; surely the real crux is to combine these two methods and then we really will know what happens.

DR. HOLT This is in part true. The two studies were done at different times, though some of the patients have been used twice over. I am not certain that the estimation of complement metabolism by radioactive decay techniques 
in vivo would be altogether meaningful in this situation, though it ought to be done, because it seems to me that the complement conversion proportion is varying the whole time as these graphs would demonstrate. To do a single complement level, to do a single complement conversion or inactivation product level, or to do a single complement turn-over study in a patient and say that it represents his complement status would be wrong.

\section{References}

AlPer, C. A., AND Rosen, F. S. (1967) J. clin. Invest., 46, 2021 (Studies in the in vivo behavior of human C'3 in normal subjects and patients)

Clarke, H. G. M., and Freeman, T. (1968) Clin. Sci., 35, 403 (Quantitative immunoelectrophoresis of human serum proteins)

Douglas, W. (1965) Ann. rheum. Dis., 24, 40 (The digital artery lesion of rheumatoid arthritis-an immunofluorescent study)

Ellis, H. A., AND Felix-Davies, D. (1959) Ibid., 18, 215 (Serum complement, rheumatoid factor and other serum proteins in rheumatoid disease and systemic lupus erythematosus)

Franco, A. E., AND Schur, P. H. (1971) Arthr. and Rheum., 14, 231 (Hypocomplementemia in rheumatoid arthritis)

GötZe, O., AND Müller-Eberhard, H. J. (1971) J. exp. Med., 134, No. 3, pt 2, p. 90S (The C3 activator system: an alternate pathway of complement activation)

HANNESTAD, K. (1967) Clin. exp. Immunol., 2, 511 (Presence of aggregated $\gamma$ G-globulin in certain rheumatoid synovial effusions)

Hedberg, H. (1967) Acta med. scand., Suppl. 479 (Studies on synovial fluid in arthritis. (1) The total complement activity)

Hurd, E. R., LoSpalluto, J., AND ZifF, M. (1969) Arthr. and Rheum., 12, 304 (Studies on formation of leukocyte inclusions in vivo and in vitro)

$-, \ldots,-(1970)$ Ibid., 13, 724 (Formation of leukocyte inclusion in normal polymorphonuclear cells incubated with synovial fluid)

JoNSEN, J., AND KÅss, E. (1961) Acta rheum. scand., 7, 21 (Complement and complement components in diseases of possible auto-immunological pathogenesis)

Laurell, C. B. (1966) Analyt. Biochem., 15, 45 (Quantitative estimation of proteins by electrophoresis in agarose gel containing antibodies)

MARKs, J., AND CoOmBs, R. R. A. (1957) J. Hyg. (Lond.), 55, 81 (The conglutination phenomenon. XI. Immunoconglutinin in human sera)

MiesCher, P. A., AND PARONETTo, F. (1969) 'Systemic lupus erythematosus', in 'Textbook of Immunopathology', ed. P. A. Miescher and H. J. Müller-Eberhard, vol. 2, p. 675. Grune and Stratton, New York

Mongan, E. S., Cass, R. M., Jacox, R. F., and Vaughan, J. H. (1969) Amer. J. Med., 47, 23 (A study of the relation of seronegative and seropositive rheumatoid arthritis to each other and to necrotizing vasculitis)

Mustakallio, E., AND KalliomÄKI, J. L. (1968) Acta rheum. scand., 14, 83 (Observations on the relations between immunoconglutinin and rheumatoid factor)

Petz, L. D., FinK, D. J., Letsky, E. A., Fudenberg, H. H., ANd Müller-Eberhard, H. J. (1968) J. clin. Invest., 47, 2469 (In vivo metabolism of complement. I. Metabolism of the third component ( $\left.C^{\prime} 3\right)$ in acquired hemolytic anemia)

Ritchie, D. M., Boyle, J. A., McInnes, J. M., Jasani, M. K., Dalakos, T. G., Grieveson, P., and Buchanan, W. W. (1968) Quart J. Med., 37, 393 (Clinical studies with an articular index for the assessment of joint tenderness in patients with rheumatoid arthritis)

Ropes, M., Bennett, G. A., CobB, A. S., Jacox, R., And Jessar, R. A. (1959) Ann. rheum. Dis., 18, 49 (Revision of diagnostic criteria for rheumatoid arthritis)

Ruddy, S., AND Austen, K. F. (1970) Arthr. and Rheum., 13, 713 (The complement system in rheumatoid synovitis. I. An analysis of complement component activities in rheumatoid synovial fluids)

- Everson, L. K., Schur, P. H., And Austen, K. F. (1971a) J. exp. Med., 134, No. 3, pt 2, p. 259S (Hemolytic assay of the ninth complement component: elevation and depletion in rheumatic diseases)

-, Müller-Eberhard, H. J., ANd AuSten, K. F. (1971b) Arthr. and Rheum., 14, 410 (Abstract) (Direct measurement of intra-articular hypercatabolism of third complement component $\left(\mathbf{C}^{\prime} 3\right)$ in rheumatoid arthritis (RA) and systemic lupus erythematosus (SLE))

Schubart, A. F., Ewald, R. W., Schroeder, W. C., Rothschild, H. J., Bhatavadekar, D. N., and Pullen, P. K. (1965) Ann. rheum. Dis., 24, 439 (Serum complement levels in rheumatoid arthritis)

Schur, P. H., And Austen, K. F. (1968) Ann. rev. Med., 19, 1 (Complement in human disease)

- AND SANDSON, J. (1968) New Engl. J. Med., 278, 533 (Immunologic factors and clinical activity in systemic lupus erythematosus)

Sliwinski, A. J., AND Zvaifler, N. J. (1972) Clin. exp. Immunol., 11, 21 (Decreased synthesis of the third component of complement (C3) in hypocomplementemic systemic lupus erythematosus)

Townes, A. S. (1967) Johns Hopk. med. J., 120, 337 (Complement levels in disease)

— AND SowA, J. M. (1970) Ibid., 127, 23 (Complement in synovial fluid) 
Vaughan, J. H., Barnett, E. V., Sobel, M. V., and Jacox, R. F. (1968) Arthr. and Rheum., 11, 125 (Intracytoplasmic inclusions of immunoglobulin in rheumatoid arthritis and other diseases)

-, Bayles, T. B., AND Favour, C. B. (1951) Amer. J. med. Sci., 222, 186 (Serum complement in rheumatoid arthritis)

Versey, J. M. B. (1971) 'Protides of the Biological Fluids: Proc. 19th Colloquium, Bruges, 1971', ed. H. Peeters. Pergamon Press, Oxford (An automated system of two-dimensional immunoelectrophoresis)

- and Slater, L. (1973) Ann. clin. Biochem., 10, 1 (Simplified area measurement in two dimensional immunoelectrophoresis)

Weinstein, A., Peters, K., Brown, D., ANd Bluestone, R. (1972) Arthr. and Rheum., 15, 49 (Metabolism of the third component of complement (C3) in patients with rheumatoid arthritis)

Winchester, R. J., Agnello, V., ANd Kunkel, H. G. (1970) Ann. N.Y. Acad. Sci., 168, 195 (The joint-fluid $\gamma$ Gglobulin complexes and their relationship to intra-articular complement diminution)

- KunKel, H. G., AND AGNello, V. (1971) J. exp. Med., 134, no. 3, pt 2, p. 268 S (Occurrence of gamma globulin complexes in serum and joint fluid of rheumatoid arthritis patients. Use of monoclonal rheumatoid factors as reagents for their demonstration)

ZVAIFLER, N. J. (1969) J. clin. Invest., 48, 1532 (Breakdown products of C'3 in human synovial fluids) 